\title{
Research mired in Homeland Security delays
}

Geoff Brumfiel

Researchers hoping for financial support from the newly formed US Department of Homeland Security are increasingly anxious that their grant requests will not be answered - this year, at least.

The department was established in January by the amalgamation of several existing agencies, and was allocated $\$ 554$ million for its research and development arm for this financial year, which ends on 30 September.

Charles McQueary, undersecretary for science and technology at the department, has indicated that most of that money will initially be spent on technology, rather than science (see Nature 423, 106; 2003) particularly on efforts to harness available technology for the Coast Guard, border guards and emergency first-responders.

Several researchers in subdisciplines such as chemical sensing and microbiology say they were nevertheless encouraged by their

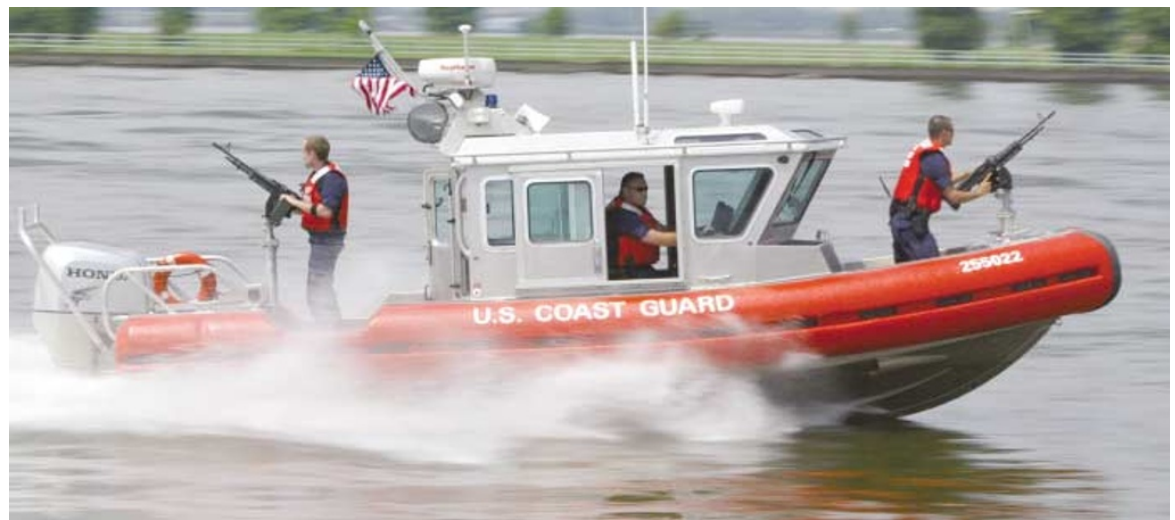

Full speed ahead: the Coast Guard has brand new equipment — but researchers remain empty-handed.

existing funding agencies - and by officials from the homeland security department itself — to apply to it for grants.

Now they are upset that no money is forthcoming. "It seems like a bureaucratic morass," complains Art Snow, a chemist

\section{Postdocs show independent spirit}

\section{Erika Check, Washington}

Establishing just the right degree of independence is critical to forging successful relationships between postdoctoral fellows and their mentors, according to a survey at the US National Institutes of Health (NIH).

NIH officials have been probing the links between postdocs and their supervisors as part of an effort to address long-standing worries about how fairly postdocs are treated as they struggle to work their way up into permanent researchers' positions. The issue is becoming more urgent, as more and more postdocs take several fellowships before this happens.

The survey by the NIH's postdoctoral association of 500 of the roughly 3,000 postdocs at the agency's main campus at Bethesda, Maryland, found that $39 \%$ of

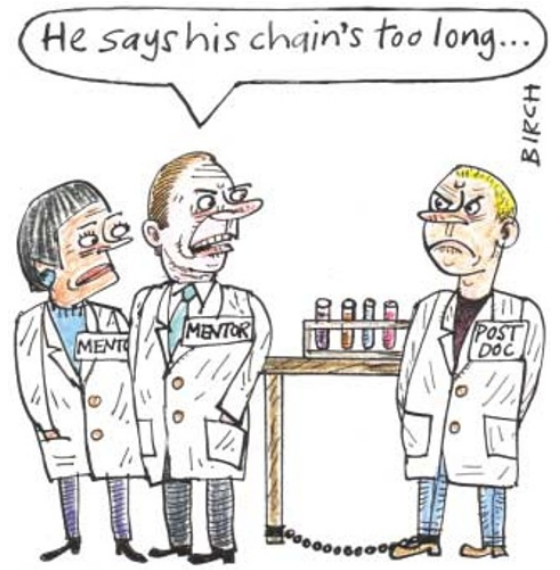

them had done at least one fellowship before arriving at the NIH.

One finding was that those most pleased with their mentors got what they said was "the right amount" of independence. Those who felt they got too much independence, like those who thought they got too little, were less satisfied.

"Hopefully postdocs will think independently - but our experience as mentors can help bring a focus to their projects," says Ed McCabe, physician-inchief at the Mattel Children's Hospital at the University of California at Los Angeles and co-author of a book on academic careers.

The issues raised in the survey will be discussed at a workshop this October led by Ruth Kirschstein, an adviser to the NIH director, which will make recommendations about what the agency should do to improve the postdoctoral experience.

Kirschstein says that the NIH has been talking to the National Postdoctoral Association, a group set up this year by postdocs in the United States. Claudina Stevenson, a founder of the association and a cell biologist who has a postdoctoral fellowship at the National Cancer Institute, says she hopes that the discussions will lead to a more proactive approach from some supervisors to postdocs' needs.

"The first thing we want is career development, so we're well qualified to move on to the next step," Stevenson says. "And that doesn't take a lot of money." http://felcom.nih.gov/mentoring/survey.html working on sensors at the Naval Research Laboratory in Washington DC. Snow says that he applied for funding earlier this year but has since become frustrated by the lack of communication over what kind of proposal its research wing is seeking. "I don't know how to prepare to work with them," he says.

One physicist at a Department of Energy laboratory, who declined to be identified, says he was told that Pentagon funding for his work in detecting chemical agents was ending, and that the new department was his best bet for future support - even though it is not yet ready to offer grants. As a result, he says, his research team is now starting to break up. And a microbiologist who works on bacterial detection at a southeastern university says that the defence department asked him to turn to the homeland security department for funds. "Everybody is saying somebody that else will do it," he says. "And I'm out of money."

Officials at the homeland security department, which is sitting on some 3,000 unsolicited research proposals, concede that its programmes have been delayed: so far, they say, only about half of the money due to be released by 30 September has been spent. The amount is "not as much as we would have liked", says an official at the department's science and technology branch who declined to be named.

But the official points out that the agency's budget for the year wasn't finalized by Congress until March. He says that he expects the situation to improve in the autumn.

The official said last week that the Homeland Security Advanced Research Projects Agency - a branch of the department modelled on the Defense Advanced Research Projects Agency - will ask for research proposals "within a matter of days". It also plans to establish its first university-based research centres in November. These moves, he says, will provide more definitive points of contact for researchers hoping to get their work funded by the department. 


\section{Biology favoured in Japanese funding plan}

Tokyo The life sciences look set to prosper while engineering research is squeezed, under budget proposals released by Japan's science ministry last week.

Japan's budget process involves ministries pitching high, projecting what they would like to spend. The government - guided, in the case of science spending, by its Council for Science and Technology Policy — will pare down these proposals to match the limited funds available in 2004.

In its proposal, the Ministry of Education, Culture, Sports, Science and Technology seeks an increase of $21 \%$, taking its research spending to $¥ 949$ billion (US\$8 billion). It won't get that much, observers say, but its proposal shows where priorities lie: life sciences gets $26 \%$ and nanotechnology $35 \%$, for example, whereas nuclear research gets $10 \%$ and aerospace programmes just $9 \%$.

\section{Michigan unveils major life-sciences institute}

Washington Michigan's bid for prominence in biology research will get a shot in the arm when a \$230-million research facility opens next week.

The goal of the Life Sciences Institute, at

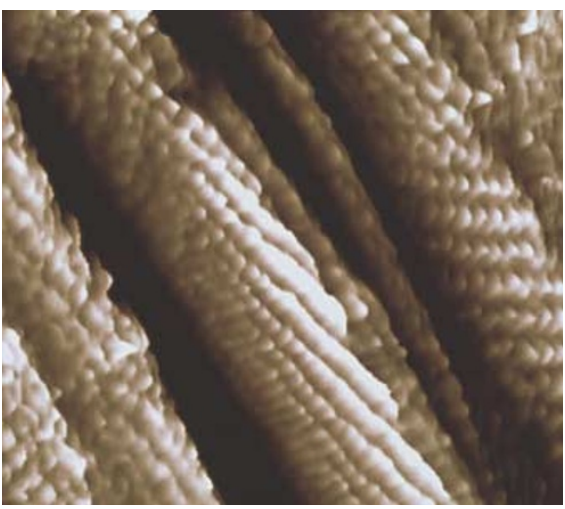

Funding for carbon nanotube research could increase under Japanese budget plans.

the University of Michigan in Ann Arbor, is to gather biologists, physicists and chemists together to foster innovative approaches to biological problems, says spokesman Karl Bates. Similar approaches are being taken at Stanford University's Bio-X project and Harvard University's Bauer Center.

The institute is good news for Michigan's efforts to become a biotechnology powerhouse, which have been scaled back because of the state's budget problems (see Nature 422, 102; 2003). The new institute has a dedicated endowment of \$130 million, unaffected by the cutbacks.

www.lifesciences.umich.edu
Universities armed with cash for biotechnology

Washington The US Army is to give three universities $\$ 50$ million over five years to develop military products using biotechnology.

The Institute for Collaborative Biotechnologies, to be led by the University of California, Santa Barbara (UCSB), will focus on three areas: sensors and electronics, biologically inspired new materials, and biological methods of information processing.

"The inspiration for the institute comes from the fact that biology uses precise mechanisms to produce exquisitely structured materials," says Robert Campbell of the Army Research Office in Research Triangle Park, North Carolina.

UCSB will work with the Massachusetts Institute of Technology and the California Institute of Technology on the project.

\section{Correction}

An article about research funding at the newly formed US Department of Homeland Security incorrectly stated that the agency had received over 3,000 unsolicited bids for research projects since it opened in January (see Nature 424, 986; 2003). In fact, that is the number of solicited proposals the agency received in its first call for grant applications, which closed on 13 June. 